\title{
Wajah IAIN Surakarta di Mata Masyarakat Pucangan
}

\author{
Shofwan Anwar Abdul Rauf \\ IAIN Surakarta
}

\begin{abstract}
This study aims at describing Pucangan society in Kartasura district towards IAIN Surakarta. High education influences social change either positive or negative effects. This study emplys qualitative method, wehereas main sources of this research takes for granted derived from Pucangan society, which is interviewed. This study looks at institute's influences from many aspects such as religion, social, economics, and education. The results shows Pucangan society perception towards IAIN Surakarta exixtence, so there must be effort to establish positive image of IAIN Surakarta in Pucangan society.
\end{abstract}

\begin{abstract}
Abstrak
Penelitian ini mendeskripsikan persepsi masyarakat Pucangan di Kecamatan Kartasura terhadap keberadaan kampus IAIN Surakata. Keberadaan institusi pendidikan turut membawa dampak dalam perubahan sosial baik dalam pengaruh positif maupun pengaruh negatifnya. Jenis penelitian ini adalah deskripstif kualitatif, sedangkan sumber data primer yang diambil adalah informan warga Pucangan yang diwawancarai dan sudah tinggal lama sebelum kampus tersebut berdiri. Penelitian ini melihat pengaruh kampus dari bebrapa aspek seperti agama, sosial, ekonomi, dan pendidikan. Dari hasil telaah menunjukkan bahwa persepsi warga Pucangan terhadap keberadaan IAIN Surakarta kurang positif sehingga perlu adanya suatu upaya untuk lebih membangun image positif IAIN Surakarta di mata warga Pucangan.
\end{abstract}

Keywords: social change, Pucangan society, IAIN Surakarta, society perception 


\section{Pendahuluan}

Perubahan sosial berpotensi terjadi pada suatu kelompok masyarakat dalam kurun waktu tertentu, baik dalam skala makro maupun mikro. Bagi masyarakat adanya perubahan tersebut dapat dipandang sebagai suatu kemajuan atau kemunduran, bergantung dari berbagai dimensi yang dititikberatkan. Bentuk perubahan di dalam masyarakat dapat berupa nilai sosial, pola-pola pikir dan perilaku, persepsi terhadap suatu hal, lembaga dan struktur masyarakat, pola kekuasaan, dan interaksi sosial. Adanya peruabahan itu dapat dipengaruhi oleh faktor-faktor modernitas yang merujuk pada kemajuan ilmu pengetahuan dan teknologi. Perubahan sosial merupakan perubahan yang terjadi dalam struktur kehidupan manusia diyakini sebagai suatu peristiwa yang mempunyai proses atau mekanisme tertentu. Terjadinya proses perubahan sosial itu dapat disebabkan beberapa faktor, yaitu kontak dengan budaya lain, sistem pendidikan formal yang maju, sikap menghargai basil karya seseorang dan keinginan untuk maju, toleransi, dan sistem terbuka (Soekanto, 1982, p.302).

Perubahan sosial dalam suatu masyarakat turut membawa pada perubahan dan pengaruh kebudayaan. Perubahan-perubahan dalam kebudayaan mencakup seluruh bagian kebudayaan, termasuk kesenian, ilmu pengetahuan, teknologi, filsafat, bahkan dalam bentuk dan aturan-aturan organisasi sosial. Ruang lingkup perubahan kebudayaan lebih luas, sudah tentu ada unsur-unsur kebudayaan yang tidak dapat dipisahkan dari masyarakat. Namun demikian, setiap perubahan kebudayaan tidak perlu harus memengaruhi sistem sosial masyarakat yang sudah ada sebelumnya.

Masyarakat merupakan sebuah sistem yang terintegrasi, yakni terdiri dari subsistem yang saling memengaruhi antara satu dengan yang lainya (Parsons, 1975). Hadirnya sistem baru atau hilangnya fungsi suatu sistem pasti akan berpengaruh terhadap kestabilan sistem lainya. Sistem tersebut akan berdampak secara langsung pada proses perubahan kebudayaan. Ruang lingkup perubahan kebudayaan lebih menekankan pada ide-ide yang mencakup perubahan dalam hal normanorma dan aturan-aturan yang dijadikan sebagai landasan berperilaku dalam masyarakat. Sedangkan perubahan sosial lebih menunjuk pada perubahan terhadap struktur dan pola-pola hubungan sosial, yang antara lain mencakup sistem status, politik dan kekuasaan, persebaran penduduk, dan hubungan-hubungan dalam keluarga. Melihat unit analisis perubahan masing-masing tersebut, perubahan kebudayaan memerlukan waktu yang lebih lama dibandingkan dengan perubahan sosial. Selanjutnya (Koentjoroningrat, 1974, p.5) berpendapat bahwa kebudayaan itu dapat diwujudkan ke dalam tiga wujud, pertama wujud kebudayaan sebagai suatu kompleks dari ide-ide gagasan nilainilai, norma-norma peraturan dan sebagainya. Kedua, wujud kebudayaan sebagai suatu kompleks aktivitas kelakuan berpola dari manusia dalam masyarakat. Ketiga, wujud kebudayaan adalah sebagai hasil karya manusia

Beberapa faktor yang dapat mendorong dan memengaruhi perubahan kebudayaan meliputi hal-hal sebagai berikut. a. Perubahan lingkungan alam (musim, iklim). b. Perubahan kependudukan (jumlah, penyebaran, dan kerapatan penduduk).c.Perubahan struktursosial(Organisasi pemerintahan, politik, negara, dan hubungan internasional). d. Perubahan nilai dan sikap (sikap mental penduduk, kedisiplinan, dan kejujuran para pemimpin). Perubahan kebudayaan pada masyarakat biasanya ada yang disebabkan oleh masyarakat secara internal dan berasal dari masyarakat pendatang. Biasanya penyebab perubahan yang dilakukan oleh masyarakat internal terjadi akibat adanya kelahiran termasuk hal-hal baru. Selain itu, media yang mereka lihat biasanya akan menimbulkan pengaruh positif dan negatif bagi masyarakat itu.

Salah satu perubahan sosial yang dominan adalah pola pikir masyarakat terhadap pemahaman agama yang dalam hal ini Islam. Religiusitas dalam masyarakat dapat dipandang sebagai parameter kualitas kehidupan bermasyarakat. Karena itu, aspek-aspek yang menunjang peningkatan nilai-nilai dan implementasi keagamaan menjadi hal yang urgen. Misalnya, pembangaunan sarana ibadah 
atau lembaga-lembaga dakwah yang menjadi fasilitator penguatan nilai-nilai religiusitas. Dampak perubahan sosio-religuis yang tampak adalah berdirinya suatu lembaga baru yang sebelumnya tidak pernah ada, misalnya, berdirinya kampus IAIN Suarkarta di wilayah Pucangan, Kartasura. Keberadaan dan eksistensi kampus tersebut dimungkinkan membawa perubahan sosial dari aspek religuisitas, humanitas, dan intelektualitas. Oleh karena itu, perlu adanya kajian yang mendalam sejauh mana perubahan itu dan bagaimana urgensi transformasi nilai-nilai religiusitas yang berimplikasi pada tatanan kehidupan masyarakat yang lebih baik.

Penelitian ini menggunakan pendekatan kualitatif sebagaimana pendekatan ini sudah sangat mengakar di bidang keilmuan sosial dan humaniora (Kaplan, Liebenau, Myers, \& Wynn, 2000, p.511). Hal ini karena pertimbangan bahwa penelitian sosial merupakan suatu hal yang kompleks karena berkaitan dengan masyarakat. Peneliti juga menggunakan metode etnografi sebagai upaya mencari data di lingkungan sosial masyarakat karena metode ini mampu melihat suatu fenomena yang kompleks dengan sangat detail (Morgan-Trimmer \& Wood, 2016, p.232). Penelitian etnografi sangat membantu melihat fenomena masyrakat dengan melibatkan peneliti langsung ke dalam bagian masyarakat tersebut sehingga menghasilkan deskripsi yang mendalam (Geertz, 1992, p.12).

\section{Kondisi Umum Pucangan}

Sebagaimana judul penelitian ini tentang Wajah IAIN Surakarta di Mata Masyarakat Pucangan, maka penelitian tidak lepas dari data daerah Pucangan sebagai obyek penelitian. Pucangan adalah desa yang berada di bawah Kecamatan Kartasura, Kabupaten Sukoharjo, Jawa Tengah. Luas wilayah Desa Pucangan ini sekitar 288.222 Hektar dengan batas utara adalah Kelurahan Kartasura, batas selatan adalah Desa Sraten, batas barat adalah Desa Sambon Boyolali, dan batas timur adalah Kelurahan Ngadirejo.

Secara geografis daerah Pucangan memiliki ketinggian tanah 17 Mdpl, memiliki curah hujan yang sedang, dan memiliki topografi wilayah dataran. Jarak geografis daerah ini dari Desa Pucangan ke Kecamatan Kartasura sekitar 3 km dengan jarak tempuh 15 menit, ke Kabupaten atau Kota sekitar $24 \mathrm{~km}$ dengan jarak tempuh 45 menit, ke Ibukota Provinsi $90 \mathrm{~km}$ dengan jarak tempuh 2.5 jam, dan ke Jakarta sebagai ibukota Negara sejauh $600 \mathrm{~km}$ dengan perkiraan waktu tempuh sekitar 12 jam.

Menurut data penduduk dan tenaga kerja, Desa Pucangan memiliki jumlah penduduk lakilaki sebanyak 6674 orang, penduduk perempuan sebanyak 6942 orang, dengan kepala keluarga 4036 keluarga. Sepanjang tahun 2014, data yang tercatat di desa menunjukkan angka kelahiran lakilaki sebanyak 115 orang dan kelahiran perempuan sebanyak 106 orang. Kebanyakan masyarakat di Desa Pucangan memiliki mata pencaharian di bidang pertanian karena memang masih banyak sekali lahan sawah yang diolah.

Di bawah kepemimpinan Budiyono, S.H. sebagai kepala desa, tidak ada peraturan desa tertentu dalam mengontrol sosial masyarakat setempat. Malahan Budiyono, S.H. mencoba mengenalkan Desa Pucangan sebagai daerah penghasil emping melinjo sehingga dijadikan produk unggulan bagi masyarakat setempat. Selain itu, Desa Pucangan juga masih nguri-nguri kebudayaan Jawa dengan mengadakan acara Sadranan sebagai salah satu sarana untuk melestarikan warisan leluhur.

\section{Persepsi Masyarakat Pucangan terhadap IAIN Surakarta Agama}

Agama merupakan aspek terpenting bagi masyarakat Indonesia. Sebagai Negara yang memiliki ideologi Pancasila, warga Negara Indonesia harus mengamalkan sila pertama Ketuhanan Yang Maha Esa. Dengan kata lain, agama menjadi pondasi paling mendasar dari hidup bermasyarakat 
di Indonesia. IAIN Surakarta sebagai kampus Islam di bawah Kementrian Agama memiliki peran besar dalam memberikan pendidikan agama di tingkat perguruan tinggi. Berdasarkan UndangUndang Dasar Nomor 12 Tahun 2017 Tentang Perguruan Tinggi menetapkan pada pasal lima bahwa berkembangnya potensi mahasiswa agar menjadi manusia yang beriman dan berakwa kepada Tuhan Yang Maha Esa dan berakhlak mulia, sehat, berilmu, cakap, kreatif, mandiri, terampil, kompeten, dan berbudaya untuk kepentingan bangsa. Ilmu perngetahuan yang harus diperhatikan dan diterapkan juga harus memiliki nilai humaniora agar bermanfaat bagi kemajuan bangsa serta kemajuan peradaban dan kesejahteraan umat manusia (Presiden Republik Indonesia, 2012).

Dengan adanya Undang-Undang tersebut, IAIN Surakarta sebagai kampus Islam harus menerapkan dan menyampaikan visi misi dari hukum yang diberlakukan untuk kemajuan warga Negara Indonesia, khususnya dalam aspek sosial keagamaan. Sesuai dengan arah kebijakan dari Pendis tahun 2015 sampai 2019 menjelaskan bahwa Pendidikan Tinggi Islam harus meningkatkan akses, mutu, relevansi dan daya saing pendidikan tinggi khususnya PTKI. Oleh karena itu, strategi Pendidikan Tinggi Islam diprioritaskan pada peningkatan akses pendidikan tinggi keagamaan Islam, kualitas layanan pendidikan tinggi keagamaan Islam, peningkatan mutu pendidik dan tenaga kependidikan PTKI, peningkatan kualitas hasil penelitian atau riset PTKI dan peningkatan hasil inovasi pada PTKI (Direktorat Jendral Pendidikan Islam, 2015).

Pada bagian ini, IAIN Surakarta dinilai oleh masyarakat Pucangan sebagaimana mereka menerima dampak langsung dari keberadaan IAIN Surakarta. Dari beberapa temuan data dari hasil wawancara dan observasi partisipasi, aspek religiusitas masyarakat ternyata tidak begitu memberikan dampak signifikan, bahkan terkadang cenderung dianggap sebagai sebuah polemik. Menurut ibu Yeni, seorang pedagang di sekitar kampus berpendapat dengan kami ketika mengobrol ringan di warungnya:

"Setelah adanya IAIN Surakarta disini kemajuan dalam hal agama ada peningkatan tetapi hanya dibeberapa tempat, seperti dibangunnya pondok-pondok walaupun yang mondok di situ hanya mahasiswa, kalau masyarakat asli sini tidak ada yang mondok. dan ada beberapa orang yang terlihat lebih islami. Tetapi itu kembali ke diri masing-masing kalau di sanggrahan sini tidak ada perubahan apapun kalau menegenai agama, anak-anak kecil saja disuruh mengaji masih malas-malasan, mereka mau mengaji kalau pas Ramadan karena mereka mendapatkan makanan ketika pulang. Tetapi kalau hari-hari biasa anak-anak disini tidak mau mengaji."

Dari pernyataan Ibu Yeni yang tinggal di Sanggarahan, kelurahan Pucangan berpendapat bahwa IAIN Surakarta bagi masyarakat tidak memberikan pengaruh keagamaan secara signifikan. Tidak ada masyarakat asli yang ikut mondok karena hanya diperuntukkan untuk mahasiswa saja. Selain itu, anak-anak di daerah Sanggrahan juga tetap malas-malasan untuk berangkat mengaji kecuali ketika Ramadan saja.

Sebagaimana anak-anak adalah generasi penerus masyarakat Pucangan, tetapi mereka sedari kecil untuk belajar agama sudah malas-malasan. Banyak aspek dalam hal itu dan tidak bisa disebutkan semuanya karena Ibu Yeni juga tidak memberikan semua informasi dengan seksama karena keterbatasan waktu. Hanya saja, IAIN Surakarta sebagai kampus Islam harus bisa menyadari bahwa anak-anak perlu diperhatikan sebagai upaya untuk penanaman keagamaan sedari kecil, terlebih lagi IAIN Surakarta sebagai kampus Islam yang mengemban amanah sesuai dengan Undang-Undang Nomor 12 Tahun 2017 Tentang Perguruan Tinggi bahwasannya lembaga pendidikan tinggi harus memberi manfaat untuk masyarakat. Apabila untuk masyarakat sekitar saja tidak merasakan dampak 
yang nyata tentang keberadaan kampus apalagi dampak masyarakat secara luas.

"Di daerah sini jarang banget yang jamaah di masjid mahasiswanya juga jarang pergi ke masjid untuk jamaah, hanya beberapa saja."

Hal lain yang lebih miris lagi dari pernyataan ibu Yeni dari Sanggrahan menerangkan bahwa masyarakat daerah Sanggrahan jarang yang ikut salat berjemaah di masjid. Tidak hanya masyarakatnya saja, melainkan juga mahasiswa juga jarang yang pergi ke masjid untuk salat berjemaah. Pernyataan tersebut sebagai bentuk kritik keras terhadap pengaruh IAIN Surakarta sebagai kampus Islam. Mahasiswanya yang diharapkan dididik dengan pendidikan umum dan agama seharusnya mengamalkan dan mengaplikasikan apa yang didapatkan. Faktanya, masyarakat melihat mahasiswa menjadi bagian dari masyarakat yang sebelumnya dan tidak memberikan titik cerah sebagai contoh mahasiswa IAIN Surakarta yang memiliki intelektual dan karakter islami.

Ditambah lagi, pemberitaan terorisme yang sempat menimpa salah satu mahasiswa IAIN Surakarta sebagai pelaku terorisme menjadi aspek paling negatif dari masyarakat. Desember 2016 merupakan saksi bahwa nama IAIN Surakarta tercoreng karena salah satu mahasiswanya adalah pelaku bom panci yang akan beraksi di Istana Negara (DM, 2016). Dari kejadian tersebut, respon masyarakat sangat beragam mengenai IAIN Surakarta sebagai kampus negeri Islam. Sebagaimana respon Ibu Yeni tentang kasus tersebut dinyatakan demikian:

“...Apalagi ini Institut Islam, masyarakat inginnya adem ayem karena Islam kan rahmatan lil 'alamin rahmat bagi seluruh alam. Jangan sampai ada yang mengatakan Islam itu adalah teroris. Masyarakat sangat menginginkan mahasiswa setelah lulus dari kampus ini bisa bermanfaat bagi yang lain bukan malah menjadi teroris dan lain sebagainya, karena sayang kan kalian semua kuliah bertahun tahun kalau tidak mendapatkan..."

Dari pernyataan tersebut sudah sangat jelas bahwa masyarakat melihat kejadian terorisme yang melibatkan mahasiswa IAIN Surakarta menjadi nilai paling negatif sejauh ini. Sebagai kampus Islam seharusnya IAIN Surakarta mendidik mahasiswanya untuk bisa membawa Islam pada citra positif dan rahmatan lil alamin.

\section{Ekonomi}

Bagi Selo Sumardjan yang dikenal sebagai bapak sosiologi Indonesia sewaktu SMA mungkin mengenalkan manusia adalah makhluk sosial tetapi bagi kacamata ekonomi, manusia adalah homo economicus yang merupakan istilah teori ekonomi untuk mendeskripsikan manusia sebagai makhluk rasional dan memiliki rasa ketertarikan (Sumardjan, 2017).

Saat ini ekonomi menjadi aspek paling mendasar untuk bisa bertahan hidup. Hal ini seperti pendapat Maslow dalam bukunya Motivation and Personality menerangkan bahwa manusia memiliki motivasi yang tidak bisa dihindari (Maslow, 1970). Pandangan Maslow dalam melihat motivasi digambarkan dengan piramida kebutuhan dengan konsep mendasarnya adalah kebutuhan psikologis, kebutuhan rasa aman, kebutuhan rasa cinta, kebutuhan sistem, kebutuhan kognisi, kebutuhan estetis, dan aktualisasi diri (Passer \& Ronald E. Smith, 2009).

Dari pandangan Maslow mengenai motivasi sendiri, hal mendasar dari motivasi manusia adalah kebutuhan psikologis dan rasa aman. Dalam hal ini, bisa diterjemahkan sebagai relevansi dengan finansial support, yaitu nilai tukar ekonomi untuk memenuhi kebutuhan motivasi manusia yang paling dasar. Untuk memenuhi kebutuhan psikis, manusia memerlukan makan dan minum 
yang saat ini tidak bisa didapatkan dengan begitu saja melainkan harus dengan nilai tukar rupiah. Selain itu, rasa aman yang bisa didapatkan dengan berlindung dari panas dan hujan adalah rumah yang tidak lepas dari nilai ekonomi yang tinggi di dalamnya.

Ekonomi selalu berakaitan dengan banyak aspek kehidupan manusia sehingga aspek ekonomis sering menjadi hal paling mendasar manusia melakukan sebuah tindakan baik maupun buruk. Pada penelitian ini melihat IAIN Surakarta sebagai sarana meningkatkan ekonomi masyarakat. Apakah memang IAIN Surakarta menjadi salah satu upaya dalam meningkatkan perekonomian masyarakat sekitar atau ternyata IAIN Surakarta sebagai kampus Islam hanya sebagai bangunan yang besar di tengah-tengah masyarakat saja.

Menurut Ibu Yeni dalam percakapan kami menunjukkan bagaimana antusiasmenya menjelaskan IAIN Surakarta sangat membantu perekonomian masyarakat sekitar. Beberapa kali dia menyebutkan bahwa IAIN Surakarta sudah membantu masyarakat Pucangan dalam menyelesaikan persoalan ekonomi yang dihadapi. Sebagaimana pernyataan Ibu Yeni dalam obrolan kami di warungnya:

"IAIN Surakarta bagus, semenjak adanya IAIN disini banyak sekali perubahan dalam hal ekonomi. banyak sekali, kemajuan di bidang ekonomi sangat meningkat seperti ibu Yeni ini yang membuka warung dari semenjak IAIN di bangun, dengan membuka warung ini saya bisa membayar biaya sekolah anak saya, bisa membayar hutang dan bisa mendapatkan keuntungan. Kalau untuk pengusaha kos itu juga sangat diuntungkan dengan adanya IAIN disini, tanah-tanah yang dahulunya satu meter 100 rb sekarang menjadi 1 jt per meter."

Pernyataan tersebut merupakan ungkapan hati paling dalam dari warga melihat bagaimana IAIN Surakarta ini memberikan banyak sekali dampak positif bagi masyarakat Pucangan dalam bidang ekonomi. Mereka melihat IAIN Surakarta sebagai magnet yang mendatangkan rezeki bagi mereka. Dengan adanya IAIN Surakarta, berbagai lowongan pekerjaan muncul dan meningkatkan pendapatan mereka cukup signifikan daripada sebelum adanya IAIN Surakarta.

"IAIN Surakarta bagus, semenjak adanya IAIN Surakarta di sini jadi maju, semuanya jadi ikut maju ekonomi masyarakat sini juga ikut maju, jalan-jalan disini juga jadi rame kalau dulu disini sepi tidak ada yang mau lewat sini karena masih alas-alas."

Selain meningkatkan perekonomian masyarakat Pucangan, ternyata IAIN Surakarta juga cukup memberikan dampak sosial, yaitu menjadikan keadaan yang sepi menjadi cukup ramai. Perubahan sosial seperti ini ternyata tidak dianggap sebagai masalah, karena mengubah tatanan sosial yang selama ini ada sebelum IAIN Surakarta dibangun, melainkan menjadikan perubahan sosial ini menjadi suatu hal yang positif bagi masyarakt Pucangan.

Namun, ada beberapa hal yang menjadi kegelisahan dan sedikit rasa kekecewaan bagi masyarakat. Sedikit kegundahan masyarakat dalam menyikapi perekonomian sekitar adalah adanya kerjasama antara lembaga, mahasiswa, dan masyarakat, seperti pernyataan yang disampaikan berikut:

“...mahasiswanya kalau dari yang dulu sama yang sekarang berbeda, dulu itu ada kong kali kong antara mahasiswa dan pedagang daerah sini kalau di kampus ada acara pedagang boleh masuk ke dalam kampus. Tapi kalau sekarang tidak bisa mereka kalau sedang ada acara mereka berjualan sendiri. Itu memang ada bagusnya untuk mahasiswa tetapi kan hubungan kerjasama dengan masyarakat menjadi agak jauh kalau dalam hal itu..." 
Dari pernyataan tersebut menunjukkan sedikit kekecewaan warga Pucangan karena absensinya mereka dalam meramaikan perekonomian dengan cara membangun kerjasama dalam berjualan di kampus ketika ada acara di dalam kampus. Apabila melihat dari sisi kebermanfaat dan humanisme dari UU No 12 Tahun 2017 yang mengharuskan kampus harus bermanfaat bagi masyarakat, memperbolehkan masyarakat berjualan di dalam kampus ketika ada acara menjadi salah satu tindakan yang nyata. Harapan dari masyarakat tersebut selalu digaungkan kepada mahasiswa tetapi karena perubahan aturan dari kampus maupun indikasi kepentingan mahasiswa dalam memperoleh dana tambahan menjadi polemik tersendiri dalam menyikapi hal ini.

\section{Sosial}

Untuk melihat dampak sosial yang diterima oleh masyarakat Pucangan, sebaiknya kita mengetahui terlebih dahulu asumsi paling fundamental mengenai teori sosial. Teori sosial mengasumsikan gambaran dari manusia sebagai aktor di dalam kehidupan. Dalam kajian teori sosial melihat tindakan manusia dan cara mereka bertindak dalam sebuah kelompok memiliki korelasi dengan masalah-masalah idealisme, materialisme, dan sebagainya (Alexander, 1988, pp.13-29).

Dalam sebuah sosial terdapat masyarakat yang tidak bisa dilepaskan. Sebagaimana masyarakat dalam bentuk sosial mengacu pada agen, gerakan, budaya, dan hubungan tersistem di dalam tindakan-tindakan kelompok keagamaan, perdagangan, politik, lingkungan, dan sebagainya. Oleh karena itu, kajian sosial dalam melihat dampak IAIN Surakarta dari persepsi masyarakat Pucangan sangat komplek dijelaskan.

Namun, ada beberapa temuan yang berhasil didapatkan untuk mengetahui persepsi masyarakat Pucangan melihat eksistensi IAIN Surakarta di tengah kehidupan sosial mereka. Beberapa gambaran mengenai persepsi masyarakat Pucanagan melihat IAIN Surakarta sebagai wajah kampus Islam diungkapkan oleh beberapa narasumber yang diwawancara.

“...Masalah kamar mandi masjid itu harus sangat perlu diperbaiki, dan kalau perlu harus di tambah lagi, karena di kamar mandi perempuan itu yang satu rusak yang satu mampet, itu harus diperbaiki, karena yang wudu dan yang salat ke masjid itu tidak hanya warga kampus, ada juga pedagang atau masyarakat yang ingin salat di situ. Karena ini kampus yang berbasis Islam seharusnya lebih tau mengenai hal kebersihan apalagi ini di kamar mandi masjid kampus..."

Dari pernyataan seorang petani yang bernama Mbah Yoto memaparkan segi sosial yang diberikan IAIN Surakarta sebagai kampus Islam kurang mencerminkan keislamannya jika dilihat dari masalah masyarakat yang merasa risih melihat kamar mandi yang rusak, mampet, dan kurang mencerminkan Islam.

Masyarakat yang ingin beribadah di masjid, khususnya pergi ke kamar mandi masjid merasa kurang nyaman dengan kebersihan rumah ibadah. Kamar mandi merupakan hal yang penting untuk diperhatikan, bukan karena aspek sosial saja, melainkan dari sisi keagamaan menunjukkan kalau seharusnya Islam itu bisa menjaga kebersihan. Fakta yang dilihat masyarakat terhadap masjid adalah jorok dan tidak layak untuk menjadi tempat menyucikan diri.

“...mereka semua ngajeni sama yang lebih tua, kalau lewat mereka menyapa monggo buk, monggo pak, tapi itu yang mau tanya dek, kalau yang pendiem yang lewat-lewat saja seperti patung, itu semua kembali ke pribadi masing-masing si dek, karena tidak semua orang sama si dek..."

Dari sisi relasional, civitas akademik IAIN Surakarta dengan norma sosial masyarakat 
Pucangan juga menjadi sorotan. Pada kasus tertentu, Mbah Yoto mencermati ada beberapa mahasiswa yang memiliki kesopanan atau ngajeni kepada orang yang lebih tua dengan menyapa menggunaan sapaan sopan seperti monggo ketika lewat di depannya.

Namun, ada juga sebagian mereka yang dianggap kurang sopan dengan masyarakat setempat karena kalau lewat-lewat saja seperti patung karena tidak menyapa sama sekali. Hal ini menjadi sorotan masyarakat karena kultur masyarakat setempat yang ngajeni orang tua sangat dijunjung tinggi sehingga ketika ada anak muda lewat di depan orang tua tanpa menyapa dianggap sebagai tindakan yang kurang menyenangkan di hati masyarakat.

“...Mahasiswa yang kost di sekitar, jarang bergaul dengan masyarakat. Ada juga yang tidak peduli dengan lingkungan sekitar. ada yang sakit, tapi malah berisik...”

Selain itu, hubungan mahasiswa yang kos di sekitar rumah warga juga mendapat perhatian khusus oleh masyarakat Pucangan. Pernyataan bahwa mahasiswa kos di sekitar tidak bergaul dengan masyarakat menunjukkan sikap masyarakat yang kurang berkenan dengan hubungan sosial yang terjadi. Terlebih lagi sikap negatif yang ditunjukkan masyarakat terhadap kelakuan mahasiswa yang kurang toleransi dengan tetangga kos yang sakit justru membuat kegaduhan dan mengganggu kenyamanan.

Namun, masyarakat Pucangan juga masih melihat tidak semua mahasiswa bisa disama ratakan. Ada beberapa mahasiswa yang dianggap sangat baik karena memiliki hubungan sosial yang baik dengan masyarakat. Hal ini ditunjukkan dengan sikap warga ketika menjelaskan bahwa ada mahasiswa yang bagus di antara mahasiswa yang dianggap negatif.

“...Ada juga mahasiswa yang begitu perhatian dengan masyarakat sekitar, sampai pernah membantu dan mengantarkan warga yang sakit...”

Pernyataan tersebut sangat menguatkan bahwa tidak semua mahasiswa bisa disamakan satu sama lain. Oleh karena itu, IAIN Surakarta perlu memberikan pengarahan secara seksama untuk bisa mengimplementasikan UU Nomor 12 Tahun 2017 Tentang Perguruan Tinggi harus memiliki manfaat. Salah satu manfaat nyata dari mahasiswa untuk masyarakat adalah tidak mengganggu kenyamanan masyarakat.

\section{Pendidikan}

Pendidikan adalah hal penting dalam kehidupan manusia. Bagi Freire, pendidikan adalah pembebasan. Dalam hal ini, pendidikan sebagai upaya masyarakat untuk memahami fenomena masyarakat. Dari fenomena masyarakat tersebut, banyak sekali masalah yang muncul sehingga perlu dipecahkan untuk mengakhiri suatu masalah. Pendidikan dalam hal ini berupaya untuk melihat dampak IAIN Surakarta terhadap pendidikan masyarakat sekitar, sebagaimana UUD Nomor 12 Tahun 2017 Tentang Perguruan Tinggi bahwa lembaga pendidikan tinggi harus memiliki dampak nyata bagi masyarakat, khususnya dalam pendidikan.

“...IAIN itu dek yang minat justru bukan dari orang asli sini, tapi biasanya mereka yang jauh-jauh yang kuliah disini. Orang-orang asli sini minatnya di UNS dek...”

Pada pernyataan tersebut ada indikasi ironi. Hal ini karena masyarakat Pucangan yang notabenenya hidup berdampingan dengan masyarakat sekitar justru memilih menyekolahkan 
anaknya di Universitas Negeri Sebelas Maret. Memang tidak bisa dipungkiri bahwa secara akreditasi dan fasilitas yang dimiliki Universitas Negeri Sebelas Maret jauh lebih unggul daripada Institut Agama Islam Negeri Surakarta. Namun, keunggulan IAIN Surakarta adalah pembelajaran agama yang sangat ditekankan dalam setiap materi perkuliahan yang ada.

Berdasarkan pernyataan masyarakat Pucangan tersebut, IAIN Surakarta masih memiliki pekerjaan rumah yang cukup besar, yaitu meyakinkan warga sekitarnya bahwa IAIN Surakarta tidak hanya sebagai magnet perekonomian masyarakat, melainkan juga meyakinkan masyarakat Pucangan bahwa IAIN Surakarta memiliki kualitas pendidikan yang uggul dan siap berkompetisi dengan kampus-kampus negeri lainnya.

\section{Kesimpulan}

Keberadaan kampus IAIN Surakarta turut memberikan pengaruh bagi masyarakat Pucangan, Kartasura baik dari perspektif dan negatifnya. Beberapa hasil temuan dari pengaruh keberadaan IAIN Surakarta sebagai berikut. (1) Dari sisi agama terdapat signifikasi dari peran masjid yang melibatkan peran civitas akademika. Namun demikian, keberadaan kampus ini belum bisa mendukung penguatan nilai-nilai religiusitas masyarakat Pucangan karena faktor lain seperti pengaruh luar dan kontinuitas kerja sama kampus dengan masyarakat. (2) Masalah sosial masih sering terjadi terutama terkait interaksi pendatang, khususnya mahasiswa yang indekos, yang tidak mampu bertadaptasi dengan maksimal dengan masyarakat setempat. (3) Pada sektor ekonomi keberadaan IAIN memang sangat menguntungkan. Hal ini dapat dilihat semakin banyak warga yang membuka warung-warung, indekos, dan berbagai sektor jasa yang lain. (4) Persepsi warga Pucangan dari segi pendidikan dapat dikatakan belum memenuhi ekspektasi. Dari penuturan warga, kebanyakan putra-putri usia masuk perguruan tinggi justru berharap mengambil kuliah di perguruan tinggi negeri lainnya, seperti UNS atau mencari perguruan tinggi swasta ternama.

Segenap civitas akademika IAIN Surakarta perlu banyak bersosialisasi dengan memberikan aksi nyata kepada masyarakat Pucangan. Diperlukan suatu perumusan program masyarakat yang terstruktur dengan baik dan diharapkan dapat berjalan secara berlanjut. Dengan program dan hasil kerja yang nyata diharapkan dapat memberikan persepsi positif terhadap keberadaan IAIN Surakarta. 


\section{Referensi}

Alexander, J. C. (1988). Action and Its Environments. New York: Columbia University Press.

Clifford Geertz. (1992). Tafsir Kebudayaan. Yogyakarta: Kanisius.

Direktorat Jendral Pendidikan Islam. (2015). Arah Kebijakan dan Strategi Pendidikan Islam

Tahun 2015-2019. Retrieved from http://pendis.kemenag.go.id/index.

php? $\mathrm{a}=$ artikel\&id $2=$ strategipendis

DM, B. (2016). Terduga Teroris Selama Indekos di Kartasura Tidak Mencurigakan. Retrieved from https://www.antaranews.com/berita/601197/terduga-teroris-selama-indekos-dikartasura-tidak-mencurigakan

Kaplan, B., Liebenau, J., Myers, M. D., \& Wynn, E. (2000). Learning and Teaching Qualitative Research: A View from Reference Disciplines of History and Anthropology.

Organizational and Social Perspectives on IT, 511-515.

Koentjoroningrat. (1974). Pengantar Ilmu Antropologi. Jakarta: Rieneka Cipta.

Maslow, A. H. (1970). Motivation and Personality. English: Harper \& Row, Publishers, Inc.

Morgan-Trimmer, S., \& Wood, F. (2016). Ethnographic methods for process evaluations of complex health behaviour interventions. Trials, 17(1), 232. https://doi.org/10.1186/s13063016-1340-2

Parsons, T. (1975). The Present Status of "Structural-Functional" Theory in Sociology." In Talcott Parsons, Social Systems and The Evolution of Action Theory. New York: New York: The Free Press.

Passer, M. W., \& Ronald E. Smith. (2009). Psychology: The Science of Mind and Behavior. New York: McGraw-Hill.

Presiden Republik Indonesia. (2012). UNDANG-UNDANG REPUBLIK INDONESIA NOMOR 12 TAHUN 2012 TENTANG PENDIDIKAN TINGGI. Retrieved from http://risbang. ristekdikti.go.id/regulasi/uu-12-2012.pdf

Soekanto, S. (1982). Fungsionalisme Impretive. Jakarta: Rajawali.

Sumardjan, S. (2017). Homo Economicus. Retrieved from http://www.businessdictionary.com/ definition/homo-economicus.html 